\title{
Peningkatan Pengetahuan Suku Moi Terhadap Pemanfaatan Dan Keberlanjutan Tanaman Sagu
}

\author{
Mira Herawati Soekamto ${ }^{1}$, Ponisri ${ }^{1}$, Reijeng Tabara ${ }^{2}$ \\ ${ }^{1,2}$ Fakultas Pertanian, Universitas Muhamamdiyah Sorong, Indonesia \\ ${ }^{3}$ Fakultas Ekonomi, Universitas Nani bili Nusantara, Indonesia \\ mira.soekamto@gmail.com
}

\begin{abstract}
ABSTRAK
Sagu sebagai tanaman penghasil pati saat ini merupakan jenis tanaman yang tumbuh melimpah secara alami di daerah Indonesia Timur seperti pada daerah Kampung Jeflio yang terletak di Distrik Mayamuk Kabupaten Sorong Propinsi Papua Barat. Keberadaan yang melimpah tidak menjadikan daerah ini memiliki taraf kesejahteraan masyaratat yang tinggi. Factor tingkat pengetahuan yang rendah menjadi hambatan utama dalam pengelolaan tanaman sagu menjadi produk yang bernilai ekonomi. Melalui kegiatan penyuluhan yang dilakukan dengan pemberian materi tentang pemanfaatan dan keberlanjutan tanaman sagu melalui budidaya akan meningkatkan pengetahuan masyarakat tentang arti penting sagu bagi mereka. Hasil kegiatan yang dilakukan menunjukkan terjadi peningkatan pengetahuan dari hasil evaluasi yang dilakukan yaitu pemanfaatan tanaman sagu sebesar 50\% dan keberlanjutan tanaman sagu melalui proses budidaya sebesar 51.67\%. dengan kenaikan ini membuktikan terjadi transfer pengatahuan kepada masyarakat Suku Moi yang mendiami kampung jeflio.
\end{abstract}

Kata kunci : Pengetahuan, Suku Moi, Pemanfaatan, Keberlanjutan, Sagu

\section{Increasing the Moi Tribe's Knowledge of the Utilization and Sustainability of Sago Plants}

\begin{abstract}
Sago as a starch-producing plant is currently a type of plant that grows naturally in eastern Indonesia, such as in the Jeflio village area, which is located in Mayamuk District, Sorong Regency, West Papua Province. Its abundant existence does not make this area a high level of social welfare. The low level of knowledge factor is the main obstacle in the management of the sago plant into an economically valuable product. Through outreach activities carried out by providing material on the utilization and sustainability of sago plants through cultivation, it will increase public knowledge about the importance of sago for them. The results of the activities carried out showed that there was an increase in knowledge from the results of the evaluation carried out, namely the use of sago plants by $50 \%$ and the sustainability of sago plants through the cultivation process of $51.67 \%$. This increase proves that there has been a transfer of knowledge to the Moi people who live in the Jeflio village.
\end{abstract}

Keywords: Knowledge, Moi Tribe, Utilization, Sustainability, Sago

\section{PENDAHULUAN}

Peningkatan produksi pangan terus dilakukan oleh pemerintah sebagai upaya untuk memenuhi kebutuhan penduduk yang setiap tahun terus meningkat. Namun upaya yang dilakukan masih menemui banyak hambatan seperti adanya penurunan kualitas lahan yang tidak bisa dihindari sebagai dampak dari pola budidaya yang salah pada tanaman dalam jangka waktu tertentu, sehingga target program swasembada pangan yang terus dicanangkan pemerintah belum mencapai keberhasilan. 
Tanaman sagu merupakan tanaman penghasil dan penyimpan karbohidrat terbesar diantara berbagai tanaman lainnnya. Dari laporan Ishizaki (1996) yang menyatakan bahwa diantara berbagai macam tanaman, sagu mempunyai produksi terbesar penghasil karbohidrat untuk satu hektar lahan dengan perbandingan produktivitas dengan tanaman lain yaitu sagu 10-15 ton/ha/thn, Padi 3 ton/ha/thn, jagung 5 tohn/ha/thn, kentang 2.5 ton/ha/thn, ubi 5-6 ton/ha/thn dan ubi jalar 5.5 ton/ha/thn. Ditunjang dengan potensi yang sangat besar terhadap keberadaan tanaman sagu karena 50\% sagu yang terdapat di dunia berasal dari Indonesia (Flach1983), dan 90\% yang terdapat di Indonesia mempunyai penyebaran berada pada wilayah Papua dan Maluku (Lakuy dan Limbongan 2003). Dengan keunggulan ini maka seharusnya negara kita tidak mengalami kekurangan dalam kebutuhan pangan.

Namun kenyataan yang terjadi saat ini, pemerintah tetap masih mengandalkan impor beberapa komoditas pangan dari negara lain. Hal ini membuktikan bahwa negara kita masih belum memenuhi kebutuhan pangan dalam negeri.

Langkah pemerintah untuk meningkatkan produksi pangan membuat arah kebijakan dan strategi dalam meningkatkan pangan yang salah satunya adalah dengan maka pemerintah juga telah mengeluarkanarah kebijakan dan strategi dalam meningkatkan produksi pangan yang salah satunya adalah Meningkatkan pemanfaatan dan pengolahan sumber daya pangan lokal sesuai potensi wilayah.

Kampung Jeflio merupakan kampung yang terletak di Distrik Mayamuk Kabupaten Sorong yang mempunyai potensi yang besar dalam pengembangan sumberdaya local karena memiliki potensi pada tanaman sagu. Dengan kelimpahan tanaman sagu bisa dipastikan bahwa penduduk Kampung Jeflio mempunyai ketersediaan pangan dan tingkat kesejahteraan yang tinggi yang berasal dari pengelolaan tanaman sagu, namun hal ini tidak dibuktikan dengan kenyataan yang ada karena rendahnya pengetahuan menyebabkan pengelollan masih terbatas sehingga hampir dipastikan akan terjadi pergeseran komsumsi sagu kepada konsumsi beras dan untuk kedepannnya bahkan sagu ini akan semakin hilang keberadaannya sebagai makanan pokok.

\section{METODE PENELITIAN}

Kegiatan pengabdian dilakukan dengan sasaran utama dalam transfer pengetahuan yaitu Suku Moi yang berada di Kampung Jeflio. Kegiatan dilaksanakan pada BulanAagustus 2019 dengan tahapan kegiatan mulai dari perisiapan hingga pelaksaan dan evaluasi akhir dari kegiatan. Metode pelaksanaan pengabdian ini dilakukan dengan cara yaitu: Ceramah yang disampaikan oleh pakar yang mempunyai pengetahuan dan pengalaman terhadap berbagai pemanfaatan tanaman sagu dan bagaimana pengelolaan keberlanjutan tanaman sagu. Diskusi dilakukan setelah proses pemberian materi yang dilakukan antara pembawa materi dengan peserta kegiatan sosialisasi yaitu Suku Moi tentang hal-hal yang berkeiatan dengan materi yang diberikan. Evaluasi umpan balik, ditujukan untuk melihat seberapa besar transfer pengetahuan yang terjadi setelah kegiatan sosialisasi ini kepada peserta, apakah ada peningkatan atau 
tidah dari pelaksanan kegiatan ini. Kegiatan ini dilakukan sebelum dan sesudah kegiatan sosialisasi dengan memberikan kuisioner yang pernyataannnya disesuaikan dengan materi yang diberikan.

\section{HASIL DAN PEMBAHASAN}

Dari hasil pelaksanaan kegiatan penyuluhan/sosialisasi menunjukkan bahwa adanya antusias dari peserta untuk mengikuti kegiatan ini. Hal ini terllihat dari adanya kehadiran dalam mengikuti kegiatan penyuluhan dan dialog interaktif antara pemateri dan peserta tentang sistem budidaya tanaman sagu yang benar. Harapan dari kegiatan ini yaitu peningkatan pengetahuan juga dapat dicapai dengan ditandai adanya kenaikan tingkat pengetahuan peserta dari apa yang telah diberikan. Rata-rata besarnya peningkatan pengetahuan masyarakat dapat dilihat pada tabel 1 .

Tabel 1. Rata-rata Tingkat Pengetahuan Sebelum Dan Sesudah Kegiatan Penyuluhan Tentang Pemanfaatan Dan Keberlanjutan Tanaman Sagu.

\begin{tabular}{llcc}
\hline No. & \multicolumn{1}{c}{ Jenis Materi } & Sebelum $(\%)$ & Sesudah (\%) \\
\hline 1. & Pemanfaatan Sagu & 40.00 & 90.00 \\
2 & Budidaya Tanaman Sagu & 33.33 & 85.00 \\
\hline
\end{tabular}

Sumber: Data Primer 2019

Dari tabel 1 menunjukkan bahwa sebelum kegiatan penuluhan berlangsung, ratarata tingkat pengetahuan masyarakat terhadap pemanfaatan tanaman sagu hanya bisa menjawa sebesar $40 \%$ dari semua pertanyaan yang diberikan menyangkut pemanfaatan tanaman sagu namun setelah kegiatan berlangsung hingga selasai terjadi peningkatan sebesar $50 \%$ yaitu menjadi $90 \%$ yang bisa menjawab pertanyaan dengan benar. Sedangkan untuk pengetahuan budidaya tanaman sagu juga terjadi peningkatan dari $33.33 \%$ menjasi $85 \%$, sehingga terjadi kenaikan sebesar $51.67 \%$. dengan adanya kenaikan ini emmbuktikan adanya peningkatan pengetahuan dari peserta yang mengikuti kegiatan ini. Gambaran kenaikan tingkat pengetahuan peserta dapat dilihat dari grafik pada gambar 1 . 


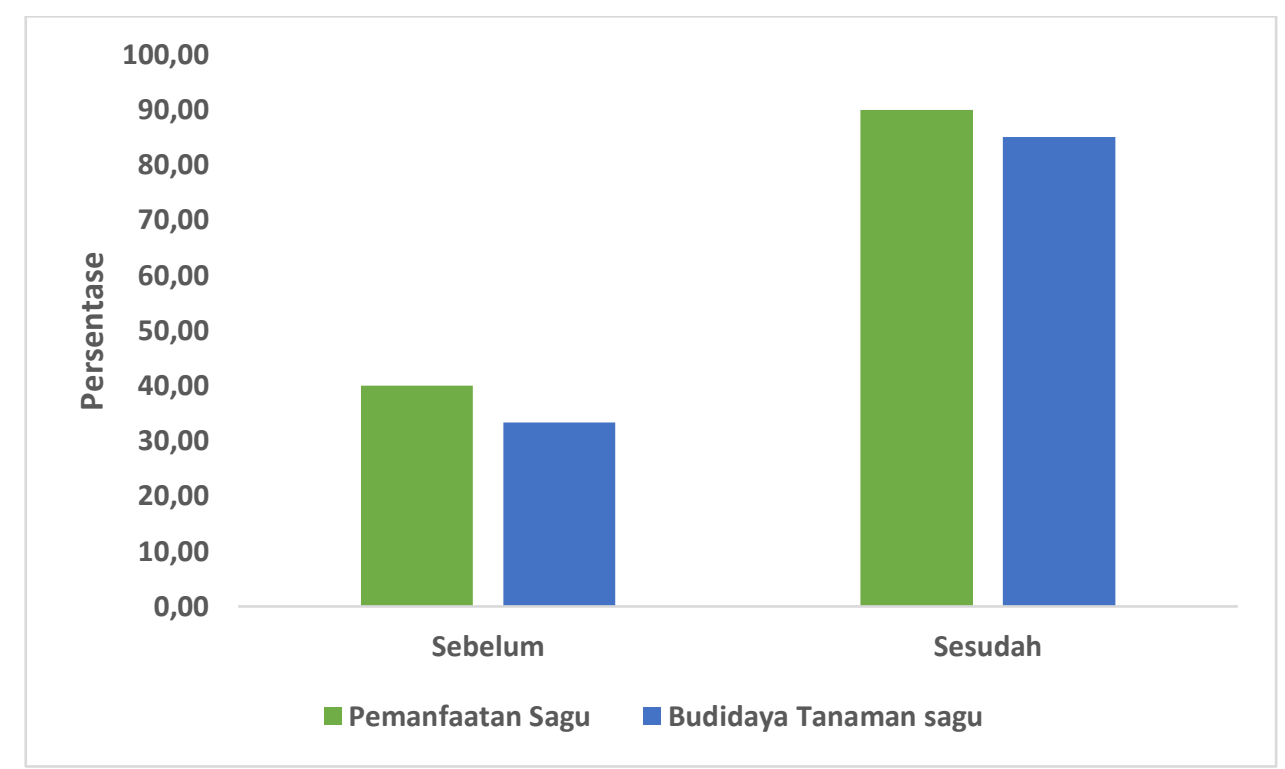

Gambar 1. Grafik Gambaran Perubahan Tingkat Pengetahuan Suku Moi dalam Kegiatan Penyuluhan Pemanfaatan Dan Keberlanjutan Tanaman Sagu.

\section{Pelaksanaan Kegiatan Penyuluhan.}

Kegiatan penyuluhan yang dilaksanakan dengan memaparkan materi tentang berbagai macam pemanfaatan tanaman sagu menjadi berbagai olahan mulai dari tepung, limbah dan atapun tanaman sagu tersebut menjadi berbagai olahan yang mempunyai nilai ekonomi yang bisa meningkatkan kesejahtaraan masayarakat. Selain itu dijelaskan materi tentang keberlajutan tanaman sagu yang selama ini tumbuh alami sehingga diberikan materi tentang budidata tanaman sagu bagi masyarakat. Proses kegiatan yang berlangsung dapat dilihat pada gambar 2 dan 3. 


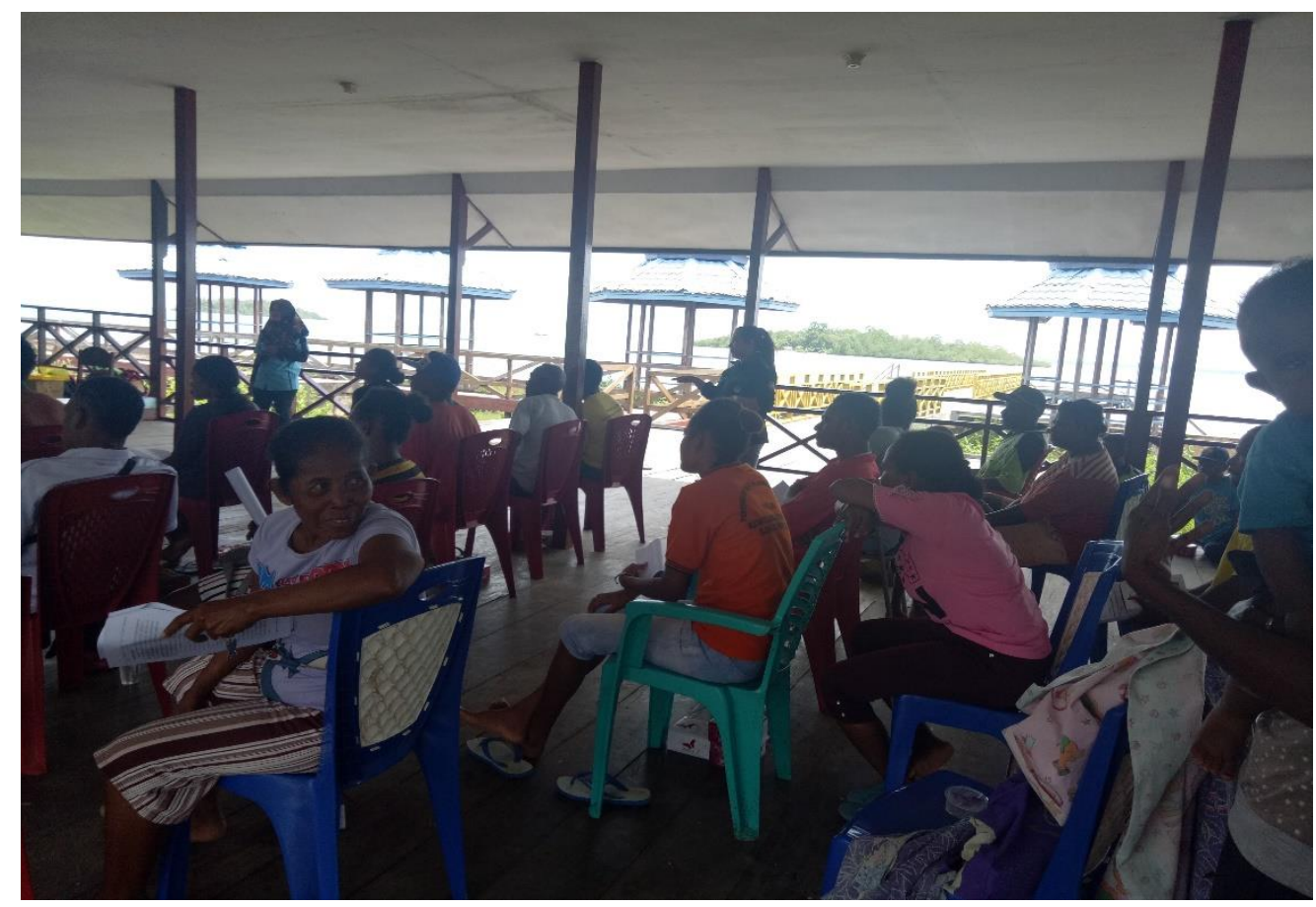

Gambar 2. Peserta Kegiatan Penyuluhan Pemanfaatan dan keberlanjutan lahan tanaman Sagu

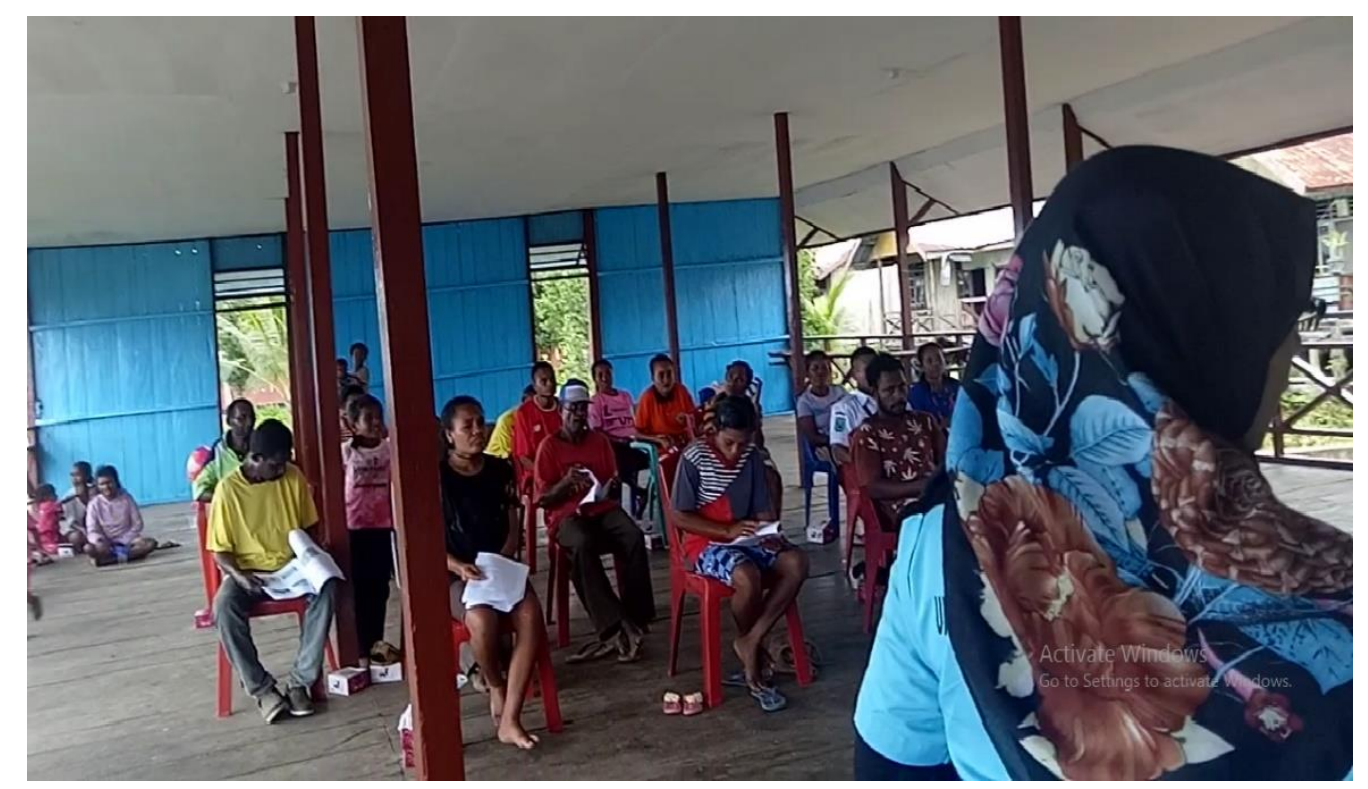

Gambar 3. Proses Kegiatan Penyluhan Berlangsung

\section{KESIMPULAN}

Melalui kegiatan punyuluhan tentang pemanfaatan dan keberlanjutan tanaman sagu yang dilakukan di Suku Moi Kampung Jeflio menunjukkan adanya peningkatan pengetahuan dari pemnafaatan tanama sagu sebesar 50\% dan keberlajutan lahan sebesar $51.67 \%$. 


\section{UCAPAN TERIMA KASIH}

Peneliti ucapkan terima kasih kepada Direktorat Riset dan Pengabdian Masyarakat Direktorat Jenderal Penguatan Riset dan Pengembangan Kementrian Riset, Teknologi dan Pendidikan Tinggi atas dana hibah pada skema Program Kemitraan Masyarakat (PKM) tahun anggaran 2019.

\section{DAFTAR PUSTAKA}

Flach, M. 1983. Sago Palm Domestication,Explantation, and Production. FAG PlantProduction and Protection Paper. 85 pp.

Hariyanto, B. (2011). Manfaat tanaman sagu (Metroxylon Sp) dalam penyediaan pangan dan dalam pengendalian kualitas lingkungan. Jurnal Teknologi Lingkungan, 12(2), 143-152.

Ishizaki, A. 1996. Sago: The Future Source of Food and Feed. Closing Remark: In Christine Jose and Aslim Rasyid (eds). Proc.Of the Sixth. Itl. Sago Symp. Pekanbaru. Indonesia.

Lakuy, H. dan J. Limbongan. 2003. Beberapahasil kajian dan teknologi yang diperlukanuntuk pengembangan sagu di Provinsi Papua.Prosiding Seminar Nasional Sagu, Manado,

Limbongan, J. (2007). Morfologi beberapa jenis sagu potensial di Papua. Jurnal Litbang Pertanian, 26(1), 16-24. 